\title{
War and Peace: Armistice Observance in British Schools in 1937 Dr Susannah Wright
}

This article examines individual narratives of armistice observance in British schools at a moment of polarized public debate about war and peace. Teachers and pupils described what they did, thought, and felt during their school's commemorations on November $11^{\text {th }}$, 1937, in accounts penned for the social research organisation Mass Observation. They experienced the symbols, rituals, and texts of acts of collective remembrance in complex ways. Whilst participating in compulsory acts of observance their articulation of a common civic act was shaped by the power dynamics and priorities of the school setting, and individual histories and ideological commitments.

Keywords: commemoration, schools, militarism, pacifism, internationalism

\section{Introduction}

At a secondary school in the North of England, at 10.50am on November $11^{\text {th }}, 1937$, staff and students assembled in the school hall. They sang a hymn ("O God our Help in Ages Past"). The headmaster read a war poem, and the names of ex-pupils of the school who had been killed in the First World War. The two minutes' silence - "absolute" - was held, followed by a talk by the headmaster given "for the sake of these lads who used to sit here where you are sitting now". He explained the meaning of the poppy, "as sign of remembrance", and described war as "perhaps the foulest thing we can experience in life" 
but also "[calling] forth the finest in men". The teacher who penned this description, and listened to the talk, felt frustrated at the headmaster's "kill-joy war psychology" and literary pretentions. Back in class afterwards, he offered pupils the opportunity to have a debate: "In the opinion of this class the ceremony which we have just attended was (consciously or unconsciously) calculated to encourage the idea that the next Great War was inevitable". Pupils seemed keen initially, but no one offered to speak for and against, so the normal French lesson was resumed.1

This teacher's account highlights the ways in which he was, alongside others in the late 1930 s, alert to the potential for acts of commemoration to normalize war. And, importantly for my purpose here, it exemplifies the different narratives about war and peace that children in schools could access through such ceremonies - the headmaster's talk, and the teacher's attempt to use classroom activities to question the import of what they had just done, seen and heard. It also shows that young people were not just passive recipients of messages and norms, but they could influence (to an extent) the nature and mode of delivery of those messages, and their response, or lack thereof, could prove significant. This teacher's plans floundered not because of pupil resistance but their inaction, whether motivated by awkwardness, by failing to see the significance of the subject matter, by shyness (it is impossible to tell from this one account alone).

That morning, acts of "collective remembrance" marking the signing of the armistice on November $11^{\text {th }}, 1918$, took place in primary and secondary schools throughout Britain. The sombre rituals described here had become familiar to contemporaries through annual repetition, and the silence, poppy wearing, and wreath-laying, perhaps also the hymn singing and prayers, will be familiar to present-day readers in Britain and nations of the Commonwealth (past and present). And if the precise order of events and symbolism is less 
familiar, underlying questions regarding the import and consequences of commemorations in the aftermath of war cross boundaries of time, space, and theatre of conflict.2 Armistice Day commemorations could support social cohesion, cultural continuity, and political authority. They could be conceived as top-down "invented traditions" which aimed, in the wake of the extension of the suffrage in 1918, to socialize individuals into a culture of responsible citizenship, and to reinforce dominant narratives of the First World War. The same rituals could also be sites of creative tension and resistance. 3 Participation in acts of commemoration was generally expected, and, as Lucy Noakes puts it, "policed". And individuals were bound by an "etiquette of commemoration"; they were expected not only to take part but to behave and think appropriately. The same collective acts, however, were experienced and interpreted in different ways. Organizations - veteran lobbies, mainstream internationalists, and by the mid-1930s pacifist groups - all seized on armistice commemorations as an opportunity to promote their cause, to persuade and educate at a time when public attention was focused on matters of war and peace. Individuals' responses to these collective events were similarly varied, influenced by their ideological commitments and own experiences and memories (or lack of direct experiences and memories) of the First World War.4

This intersection between communal narratives and events and individual responses played out in distinct ways at different sites of memorialization and commemoration. I turn my attention here to British schools, the only site of armistice commemoration where the majority of participants were children, and one which has not yet been subject to detailed scrutiny. 5 I examine a unique collection of primary sources available for the year 1937; individual accounts by 27 teachers and nine pupils, describing what they did, thought, and felt on the morning of November $11^{\text {th }}$ that year, sent to the recently-founded social research 
organisation Mass Observation. These accounts narrate individual responses in this setting to messages about war and peace conveyed through the symbols, rituals and texts of armistice commemoration. Armistice Day was one of the "special days" valued by Mass Observation's founders for their ability to "give the clue to much that is baffling in the uniform and impassive surface of everyday things". And the focus on multiple accounts of a unique historical moment allows for an examination of nuanced debates and opinions about war and peace and the place of military and militarism in schools and wider society. No single message was presented or accepted, across schools, or even by individuals whose writings can suggest ambiguity and internal conflict. 6

Findings from a small-scale, close-up, study like this are not generalizable, though some patterns can be ascertained. Yet its implications are of wider interest and significance. This study contributes a child- and school-centred focus often missing or underplayed in the rich, and growing, body of research into commemoration and remembrance after the First World War, though space precludes in-depth engagement with a vast empirical and conceptual literature. Secondly, it brings to the fore agency on the part of pupils even in the context of powerful invented traditions and the disciplinary norms and structures of the school. Children emerge as complex actors in both pupil and teacher accounts. In this respect my findings speak to ongoing debates about children's agency which consider, theoretically, its utility for conceptualising children's thoughts and actions, and, empirically, the varied and sometimes unexpected forms which agentic action and expression can take. Thirdly, messages about war and the military in schools - and indeed in wider society - are shown to be presented with ambivalence and subject to equivocal responses, and some questioning and resistance. This troubles assumptions about hegemonic messages and their absorption by pupils which can be found in research into militarism and patriotism in 
schools. Schools might have been expected to produce democratic citizens, in part through commemorative events which brought to the fore the way that a nation and the individuals comprising it engaged with the legacy of a global war. Individual teacher and pupil accounts highlight, as well as communal endeavour, tensions and complexities in this engagement. Familiar annual rituals of commemoration in 1937 took on new and potentially challenging meanings. Against a backdrop of accelerated rearmament and gas-mask fitting, of armed conflict in Poland and Spain, and concerns about the rise of totalitarianism in Europe, views about the most appropriate response to escalating tensions were aired in often polarized public debate. Rearmament for some was a necessary step which would enhance Britain's defensive capabilities and make other countries feel safer, thereby fulfilling international obligations towards collective security; for others, it would be a "threat to the peace of the world" and would render war inevitable. Air raid precautions were considered reassuring, and a means by which people could fulfil their civic obligations, but were also deemed potentially unsettling for vulnerable civilians, reminding them "that the front was on [the] doorstep". 7 The shadow of a potential war hangs over these comments, as it did for the teacher writing for Mass Observation who wanted to start a debate in his class. And unbeknownst to this teacher at that particular moment, a parallel act of questioning was going on in the very public forum of the main national commemorative event at the Cenotaph memorial in London. The silence there was interrupted for first time, by a man pushing through the royalty, other dignitaries, armed forces, and police standing there to shout words not fully audible but reported as variants of "All this hypocrisy", "Preparing for war", or "No more war". The man was later identified as Stanley Storey, First World War veteran and escapee from a lunatic asylum in London to 
which he was later returned.8 Elements of these wider debates and public events found their way into pupils' and teachers' accounts of armistice commemoration in schools.

Children attending their schools' armistice commemorations in the late 1930s would have experienced messages about war and/or peace in a powerful educative and socializing context through annually performed rituals which wrote the First World War and military heroism into national history and collective identity. And participating in these rituals, for most, was not optional. But it cannot be assumed that militaristic readings were always prominent, always intended, or always taken on. The teachers and students who contributed to Mass Observation were citizens, older and younger, who were expected to "do their duty" (this phrase recurs in accounts of Armistice Day talks), 9 but were not always comfortable doing so, and interpreted the meanings and consequences of doing their "duty" in different ways.

\section{Observing the Armistice}

For pupils attending schools in Britain in 1937 - and throughout the interwar years armistice commemoration was one of many encounters with complex ideological territory related to war and peace. Teaching texts could emphasize allied victory, and the supreme sacrifice of the War dead, situating military success (and the losses of military personnel) within patriotic narratives of national history. In boys' secondary schools, military men gave addresses on school speech days, and pupils often found themselves strongly encouraged, or obliged, to join the Officer Training Corps (OTC). Alternatively, or in some schools at the same time, pupils were encouraged to join League of Nations Union (LNU) junior branches, to read books and watch films which emphasized the horrors of the war, and generally to work for international understanding and peace.10 Such encounters with matters of war and 
peace were part of a wider contemporary agenda of educating children in schools into being active and responsible democratic citizens. This agenda was not a new one, but in the interwar years pedagogical fashions were intertwined with the legacy of the First World War within an emergent national and international political context. A sense of national self and national community, with references to a deep historical past, had to adapt to the circumstances of the time - the impact of a global war, an expanded electorate, geopolitical transformations, and the rise of totalitarian regimes. 11

Armistice commemoration in the interwar years, typically, involved remembering those in the armed forces who died in the war, and also celebrating the coming of peace. Contemporaries saw the consequences and potential of this dual narrative in different ways. For some, like the teacher cited earlier, remembrance of the war dead at armistice time, incorporating narratives of heroic sacrifice at the front, and ceremonial parading of veterans and/or serving military, rendered commemoration a potentially militarizing force, which valorized the armed forces and normalized war. For others, armistice commemoration presented an opportunity to promote aims of peace and international understanding (this was very much the internationalist reading of the LNU, for example); reflecting on losses from the First World War was intended to stimulate efforts to avoid the same happening again.12 Yet, as the discussion below indicates, whatever messages were intended, both adults and young people involved in commemorative events could question, opt out, or ignore.

A message of respectful remembrance of the war dead combined with the need to strive for peace permeated the many resources available for use in schools. Teachers could draw on local education authority guidelines, and the many resources available in educational periodicals. 13 In these texts, schools were represented as carrying a common 
agenda and responsibility, and, importantly, were expected to engage in commemorations. By participating in a national moment, they were to facilitate a form of civic engagement for the younger generation, their "initiation into national history". Some teachers, however, felt uneasy about these expectations, with qualms increasingly evident from the mid-1930s. One, in a letter in 1935, claimed that the questions he wanted to ask about war and the military were unwelcome at armistice time. In 1937, another deemed armistice commemoration irrelevant to the children he taught: the wartime generation had passed, children now were too young to understand the significance of the event, and in any case they would "soon be fitted with gas masks".14

Pupils in schools engaged in a nation-wide act of commemoration, performing the same rituals as other children, and adults, across the country, but these rituals for them were also shaped by the purposes, age-related norms, power dynamics and behavioral expectations of schools. Armistice commemoration in schools, in the 1937 Mass Observation accounts, was an occasion when teaching and learning took place, both informally through doing (engaging with the actions and symbols of collective rituals), and through listening to and reading messages embedded in the written and spoken texts of the event. The teacher described already, wanting his students to question the purpose of the ceremony they had just attended and to recognize its potential consequences, turned to the resources available to him - a classroom and a timetabled lesson. Teachers, moreover, realized that pupils might learn from the bearing and demeanor of older pupils and adults present, referencing the potential for imitation of elders to serve as what Karen SánchezEppler terms a "mechanism of ... collective memory and cultural preservation". One thought of his own youth, wondering if they were "doing as I used to do as a boy, [watching] those in authority at moments like these, gleaning what one could from their expressions". Another 
wondered why his boys remained still, "whether they understand or whether it is imitation of their elders or merely school discipline that is the cause".15 Older pupils could also attempt to teach their peers. Notwithstanding these intentions, children could, by their responses, sway agendas, or prevent messages being imparted as emphatically as was hoped.

Individual pupil responses to the collective demands of compulsory armistice commemoration described in the Mass Observation accounts varied. They included minor, typically unobtrusive, acts of rebellion or compliance with cultural traditions and norms, children agreeing or disagreeing with one another, and both intergenerational alliances and intergenerational tensions. This range of agentic responses on the part of children is comparable with those noted by historians of childhood in quite different settings. 16 Age and associated power relations in the school did not prevent children shaping, at least to some extent, the form and import of messages of armistice commemoration, whether messages which valorized military sacrifice, or advocated internationalism and pacifism, or a mixture of both. Teachers' accounts outnumber those from pupils, and this inevitably has implications for what we can ascertain about pupils' experiences, and armistice commemorations might have been structured, primarily, by "adult concerns". Yet teachers were eager to understand and read their pupils' thoughts and actions; they engaged in a form of "empathic inference". 17 What armistice commemoration meant to and for pupils mattered to them. In the context of such mass events, teachers and pupils could assume a collective, group response. But individuality, also, permeates, these accounts.

Individuality, indeed, was actively encouraged by Mass Observation. The origins of Mass Observation in January 1937 from informal meetings among left-leaning London intellectuals, notably anthropologist and ornithologist Tom Harrisson, modernist poet and 
journalist Charles Madge, and surrealist film maker Humphrey Jennings, are well rehearsed. The founders, notwithstanding methodological and political differences, agreed on statements of aims. Drawing on insights from a panel of amateur observers and trained experts, they intended an "anthropology of our own people" - "a scientific study of human social behaviour, beginning at home". Mass Observation's methods, its founders suggested, would discover what people actually did and thought, rather than the slanted version reported in papers or by commercial interests. And the act of observing would benefit observers, enabling them to better understand, and on this basis to transform, their environments. 18

During 1937, an anthropological project, involving a team of expert observers who lived, worked, and drank in pubs in Bolton, Lancashire ("Worktown"), was developed under Tom Harrisson's oversight. 1937 also saw the recruitment of a national panel of amateur volunteers, by word of mouth, newspapers, and pamphlets. Managed by Charles Madge and assistants from his home in Blackheath, and numbering about 600 by the end of that year, the panel was asked to write accounts for the $12^{\text {th }}$ of each month, and "special days" including Armistice Day. The founders' intention of recruiting a panel "from all classes, from all localities and from every shade of opinion" was not realized. Panellists were more educated, middle-class, more youthful, more male, more left-leaning in politics, and more South Eastern than was typical of the British population, and workers who left school aged 14 were underrepresented.19 Given the time and literacy demands of writing regular submissions and lack of payment, it could not easily have been otherwise. Panellists might have been amateurs, but they were not without guidance. Upon joining they were asked to send in a practice observation. They were advised to report on what happened and also on their feelings, and to observe both themselves and their neighbors. Exemplar accounts were 
published in monthly bulletins from April 1937 onwards. And panellists themselves noted heightened awareness on observation days, with one teacher writing in his Armistice Day account: "Remember that I am to 'observe'... feel that I am noticing and remembering things I should not remember in the normal way".20

The national panel was issued with the following instruction: “On Nov, 11th make a detailed account of what happens between 10.30 and 11.30am." Mass Observation's files contain 279 panellist responses, including 27 teachers and nine pupils who were present at school that day (see Table 1). Teacher and pupil panellists were not consistent in the information they provided about their school and its social milieu. Teacher panellists, nonetheless, were more male and more likely to work in secondary-schools than was typical of the teaching workforce at large. Still, more than half worked in elementary schools presumably mostly state-funded ones though this was usually not specified - with some describing "poor" or "deprived" neighborhoods. All but one of the pupil panellists were secondary school boys. At a time when secondary schooling was only available to a minority of children and mostly in fee-paying institutions with scholarships available for only a few, this was predominantly a middle-class group, but ranged from those who attended 'day' schools locally to those boarding in elite 'public' schools. The only female pupil panellist was seven and attended a preparatory school. Some, but not all, panellists mentioned religious affiliation. Those who did included Christians (from highly committed to those questioning aspects of their faith), some who defined themselves as agnostic or atheist, and one Jew.21

This group of teacher and pupil panellists overall showed considerable commitment to the Mass Observation enterprise. 23 of the 36 submitted five or more times, a proportion that compares favorably to the national panel as a whole. They bought in to the aims expressed by the founders, wanting to find out more about society, often with a goal of 
social improvement in mind. When asked to write about why they joined Mass Observation, their responses suggest a typically left-wing political milieu, with many designating themselves socialists or communists or noting Left Book Club membership. Some wanted to feel part of a progressive social or cultural "movement" which extended beyond the geographical and cultural confines of their everyday life, and deemed themselves more politically active, literary, or socially concerned than others around them. Their sense of distinctiveness inflects their Mass Observation accounts. Committed teacher and pupil panellists might well have taken the instruction to write "truthfully" and with authenticity to heart. But their accounts were framed with the aims and desires of Mass Observation's founders in mind, and, if anything, critique and individuality are likely to have been emphasized. 22

Table 1: Teacher and pupil panellists who submitted Armistice Day accounts (Source: Mass Observation Archive, Day Surveys, November 1937)

\begin{tabular}{|l|l|l|l|}
\hline & Gender & Type of school & Location (if stated) \\
\hline Teacher & Male: 15 & Infant/Primary: 15 & England: 22 \\
& Female: 12 & Secondary: 11 & Wales: 2 \\
\hline Pupil & Male: 8 & All-age: 1 & \\
& Female: 1 & Secondary: 8 & Scotland: 2 \\
\hline
\end{tabular}

\section{War and Peace in Teachers' and Pupils' Accounts}

The commemorations described by teacher and pupil panellists typically took place on school premises, in the school hall, chapel, or in larger classrooms; three went to a local war memorial or church. Participation was expected for all but one; the one who was able to 
choose whether to join in decided not to. A common pattern emerges across all accounts: poppy wearing, the two-minute silence, prayers, music, hymns (most often "O God our Help", whilst "O Valiant Hearts", "Jerusalem", and the National Anthem also recur), wreathlaying at memorials. OTCs, cadets or uniformed youth movements could play a ceremonial role. In secondary schools, the names of past scholars and teachers who had lost their lives in the First World War were often read. If accounts reveal a sense of common traditions made familiar through annual repetition, armistice commemoration was also an unusual event in the school setting, disrupting normal timetables and uses of space. A sense of discomfort is conveyed in teachers' accounts (less so, interestingly, in pupils'), not often articulated with precision, but evident in hints of a sense of relief when all were "back in their own environment", as one teacher put it. Potentially difficult and controversial ideological content had to be negotiated; commemorations required a balance to be found between militarism and patriotism, and internationalism and peace. One school's event, for example, included an OTC parade, and prayers for the King, leaders, peace, and the League of Nations.23 Talks could emphasize the sacrifice of the "dead heroes". And they could incorporate internationalist perspectives - most often through the LNU's annual armistice message to pupils - reflecting the prevalence of internationalist teaching in schools and internationalist elements in armistice commemoration more generally in the interwar years. 24

Wider public debates about the appropriateness or otherwise of armistice commemoration were enacted in staffrooms, with particular reference to implications for the younger generation. Some panellists noted differences of opinion: " $R$ ", "somewhat to the left" - "It's meaningless to the kids, and to nearly everyone else as well", but "C", a "staunch conservative" - "it is all the more necessary now, with a generation knowing 
nothing of the war". Another, older, teacher reported general agreement among colleagues: "We are all of the opinion that the time is coming when we must be content for Armistice Day to be just an event in history". During the silence, she reflected on her personal wartime losses, but wondered "how we can burden them with our griefs. How can we continue to look upon ourselves as the tragic generation when who knows what is in store for them?" 25 Teachers, indeed, were concerned with relevance and appropriateness for pupils. This could be conceived as a matter of pupils' level of understanding. Whether this was the pitching of language and concepts, or an encounter with difficult and "adult" themes and events at a remove from their experience, is not often specified. But unease is perhaps expressed through concerns that rituals, talks and texts went "over their heads". Teachers also attended to pupils' affective response. One wrote that pupils seemed to show "no emotion", but they were "evidently held", attributing their attention to an awareness of the importance of commemoration for adults around them. 26 Interestingly, pupils said little, explicitly, about age as a factor in armistice commemoration, but some mentioned a lack of relevance because they had no direct experience of the First World War, as shall be seen below. Pupils' age could, on the one hand, interact with the disciplinary norms and structures of schools to make them a captive audience for any militaristic (or other) messages conveyed, but on the other hand, their remove from the events of the First World War potentially limited the meaning and the significance for them of their school's commemorations.

The sights, sounds, objects, and personnel of armistice commemoration emphasized the military. The wearing of the red poppy, a symbol associated with the battlefields of the Western Front, and dead and maimed soldiers, was reported in nearly all teacher and pupil accounts. Panellists described poppy selling at school, or last-minute purchases on the way 
in. Pupils were told why poppies were sold, purchased and worn: to remember lives lost in battle, and to provide funds for injured veterans. Some pupils, however, questioned their peers' motivations for buying poppies, with one suggesting that they did so "merely because it was the thing to do and not because of any charitable feeling at all." 27 Cannons and maroons signalling the start and end of the silence in the locality are noted. These sounds, heard annually, could stimulate recall of previous Armistice Days. One pupil remembered, as a small boy, being taken by his mother to the window, hearing the firing of the maroon at the local police station (this was recalled as frightening), and seeing a man standing "at the salute" - his mother explained why this was done. Armistice ceremonies, nationally, featured First World War veterans and serving personnel marching or standing at ceremony. In secondary schools, the military of the present was most often represented by cadets or OTCs. Picking up on the obligation for pupils to participate in weekly training with the OTC at his school, a pupil who identified as a pacifist reported with disdain "half the school ... surging round the OTC board reading about war-instruction programme".28

Teacher panellists at schools that listened in to the Cenotaph ceremony on the wireless described their own reactions to the military band and the carrying of weapons. "The commands of the officers \& the very military form of the ceremony jarred upon me" wrote one, another disliked the "forest of bayonets". Occasional glimpses are offered of what they could discern of pupil responses; the military commands being "barked out" near the Cenotaph, writes one teacher, "jar", and "[make] many of the boys grin".29 The interruption of the silence was noted by all teacher panellists who listened in. Most reported discussions afterwards in the staffroom, out of pupil earshot, noting sympathy with the sentiments that Stanley Storey expressed as the majority opinion ("He was the sanest person in that vast assembly" was one variation on a common theme). But a minority 
questioned the appropriateness or usefulness of his outburst. No pupils heard the ceremony broadcast, but the interruption was a cause of noisy celebration in the school library among the Scottish pacifist panellists and likeminded friends, and of an argument with other pupils, when they heard about it that afternoon. 30

In talks given during commemorative events, pupils heard about the death of soldiers in war as a heroic sacrifice. One headteacher, in his version of this common trope, lauded "those who offered the greatest sacrifice of all, their own lives, in defence of their country. We must think of all such men as heroes". 31 Some panellists reported such talks without evaluative comment, others railed against the message presented. Teaches who felt there was a danger of glorifying war sought opportunities to offer a counter-narrative. The teacher mentioned at the start who had criticized the "kill-joy war psychology" in the headmaster's talk at his school, and attempted to initiate a debate in class, seems to have wanted to draw pupils' attention to the possible harm in the messages they were receiving. Another reported thinking during the ceremony, about the "sheer waste" of the First World War and feeling "annoyed, so much as to want to kick somebody". Afterwards he felt "disposed overwhelmingly to give a talk on War, and events in Spain and Japan. Not partisan, but to show the futility of it all". A third considered talking to his class "about the idea of peace and the holding of the silence" but decided to wait till his own thoughts were "a little clearer".32

Panellists were alert to normative assumptions about the proper focus of attention during the opportunity for personal contemplation offered by the two-minute silence; mourning and honoring those who died in military service. An elementary school teacher wrote, somewhat apologetically, "I'm afraid that I did not think of Flanders", finding herself distracted by the early ending of a mis-timed silence in another section of the school. 
Elsewhere in her Armistice Day account she writes that teachers in her school were expected by the headteacher, whatever their personal feelings, to set a good example for pupils; the socio-economic mix of the elementary school, as well as awareness of a wider etiquette of commemoration, might have been at stake here. Older pupils were equally aware of such norms. One considered the silence a "spiritual flop". "War is still on in the world I want to stop it \& not think about the glories of the last", he wrote. He had a sense of what he should think or feel: "I can never feel very religious \& sorrowful - I know I ought but I can't. No near relatives of mine were killed \& it does not seem to mean much." Other pupils offered no apology for their thoughts, yet still referenced a norm which they did not adhere to. One recalled his efforts as a new boy at his school to "think sadly and be very distressed over the war deaths of ... relatives I'd never seen in my life", implying that he no longer attempted to do so.33

The impact of the First World War on the school community formed a focal point for secondary school commemorations. Panellists referred to laying of wreaths on school memorials, and the reading out of names of staff and "old boys" (ex-pupils) who lost their lives. This was a poignant moment for an older male teacher who seemed, otherwise, unimpressed by the ceremony: "As the names were read I could recall the face of every boy except one [underlined in original] who I never knew." Connections between current pupils and ex-pupils who had died were emphasized. One headteacher, in his talk, referred to the old boys who used to sit in the school hall, and called on pupils present to think "what would they have liked to say to you now?" and "do our bit towards carrying on what those boys died for". Another pointed out to his Sixth Formers that during the War pupils their age went straight from school to the front and some were killed: "And they did this for their country ... that you might live to reap a ripe harvest". Values exhibited by ex-pupils who had 
fallen in the War - bravery, self-sacrifice and discipline - were held up as those which present pupils should seek to emulate and inherit. 34 If armistice commemoration generally located war and military sacrifice at the centre of a national narrative of historical development and civic engagement, then the emphasis within schools on "our" war dead located these conflicts and sacrifices at the heart of the school community, creating what Otley describes as a "military celebratory and commemoratory sub-culture". But the eulogizing of ex-pupils did not go without critique. One noted, wryly, when writing of his headmaster's prayer for those who died for King and country, and especially the "old boys" of the school, "they were of course superior to the mere workers who did so". Attending an elite boarding school, but emphasizing his own left-leaning political views, he was alert to the potential for hierarchies and divisions of class and social status in commemorations. 35 Panellists were aware that armistice commemoration could also be deemed "a definite contribution to peace propaganda", identifying this view as prevalent especially among older teachers.36 Internationalist themes could be found alongside, or as an alternative to, an emphasis on war and the military. The LNU invested time and effort from the early 1920s in armistice-time campaigning and events. Through the 1930s, it commissioned an annual Armistice Day message aimed at school pupils from a political, military, or religious authority figure. A number of panellists report the reading out of 1937's message from General Smuts, famous as First World War military leader, South African Prime Minister, and then international statesman. This message was described in negative terms by all who mentioned it. It was too pompous, too pessimistic, "a meaningless mixture of diluted economics and League of Nations propaganda". One teacher wrote of his pupils' evident boredom during the LNU message and noted in the margin of his account that the headteacher, who read the message out, had "no sympathy the League". The implication 
here seems to be that problems with the register and content of the message itself were amplified by a potential lack of sincerity in delivery. 37

Two female teachers who led parts of their school's commemorations aimed for a distinctively internationalist or even pacifist angle. They also struggled to find a register they felt comfortable with. One teacher read out a prize essay entitled "Won't people ever stop fighting?" published in the periodical Teacher's World. She deemed it "very good" but despite efforts to simplify feared that it went "above my classes' heads". Another elementary school teacher's talk for the younger children in her school is notable, firstly, for the extent of its emphasis on peace (the teacher identified as a pacifist and radical socialist in her Mass Observation submissions), and, secondly, for defining such an emphasis as particularly appropriate for children and distinct from adult readings of Armistice Day. For adults it was "Remembrance Day". For children it was to be a day of remembering other children like themselves in other lands, who played games, loved their parents, and went to school as they did, "a friendly day, peace day". She drew attention to a picture of the "Christ child stretching out arms to children of the world assembled round him" over which she had fastened a piece of cardboard with the legend "Prince of Peace", but as a non-believer felt "a hypocrite ... talking in religious strain." She aimed for a simple service and tried "not to sentimentalise [sic]", but was concerned about "saying far too much, \& praps above the children's heads".38

Panellists could express explicitly pacifist sentiment in other ways, sometimes challenging norms of their surroundings. Wearing of the white peace poppy is mentioned in three accounts. Two pacifist pupils attending a boys' school in Scotland attempted to wear white poppies to their school's Armistice Day service, but fellow pupils forcibly removed them on the way there. These pupils noted, with some pride, that the red poppy of one of 
the aggressors was crushed in the scuffle, and that they had managed to keep their white poppies on for morning prayers earlier that day. In a girl's secondary school, however, a teacher and pupil (the "school captain"), as a minority of two, managed to wear their white poppies, as well as rather than instead of red ones: "we smiled at each other across the heads". In these accounts, the white poppy had meaning and significance as an expression of pacifist sentiment in schools for those who wore or attempted to wear one, as it did in the wider civic sphere, and such an expression could elicit criticism.39

Pupils often articulated their views in ways which bore limited risk of censure. A prefect was due to read the lesson during prayers the following day: "My reading was from Proverbs \& I was rather pleased with my choice which contained 'even a fool if he holdeth his peace is considered wise'"'. He was disappointed that no one seemed to take any notice of his intended meaning. Pupils opted out of hymn singing, along with a few teachers. 40 The Scottish pacifist pupils made up their own words to "For all the Saints" and "O Valiant Heart", celebrating famous pacifists and emphasizing the horror and gore of war. After the service they dreamed up ways of interrupting the silence with a noisy music box. 41 Such actions seem to have been conceived with the aim of satisfying and entertaining those involved rather than influencing others.

\section{Conclusion}

Mass Observation was not representative of British society, and its panellists were not representative of teachers or pupils. Nonetheless its resources offer the historian a rare opportunity to access detailed descriptions of armistice commemoration in schools, and teachers' and pupils' thoughts and views, at a historical moment when readings of the armistice were subject to change. Teachers' and pupils' accounts from 1937_describe 
common invented traditions. Whatever their views about these traditions, they joined in, bound by an "etiquette of commemoration" framing what they should think, feel and do. 42 They could access a range of mainstream internationalist readings of the armistice in the public sphere, which accepted wartime sacrifice, whilst emphasizing the need for current and future peace, and could draw on these in creative ways. A pacifist, anti-war, stance proved more controversial in schools, as elsewhere. Indeed, polarized debate about matters of war and peace in the public sphere entered the school, sometimes in commentary on panellists' own thoughts and responses, sometimes in reports of discussions among staff and pupils. Armistice commemoration for panellists could be deemed an opportunity to raise awareness among the young about an event that must not be forgotten, whether primarily in order to honor the glorious dead or to avoid at all costs a repeat of war on a global scale. But for some (teachers and pupils) it was of questionable relevance for young people far removed from the experience of the First World War. And aspects of the familiar rituals of commemoration could feel inappropriate, even distasteful, when another major conflict seemed imminent. The aims of Mass Observation, and the leftleaning political milieu of many of its volunteer observers, potentially encouraged and facilitated this sort of critique, though panellists' comments were not out of step with currents of wider contemporary debate.

Panellists' experiences of the collective rituals of armistice commemoration were framed by routines, structures, disciplinary practices, and age and power relations particular to the school setting. Teachers and pupils did what they could to mediate this communal experience, working around the constraints and possibilities of this setting, making it as relevant and palatable as possible to young people who had no direct experience of the First World War. They might have followed norms of observance, sanctioned by the state and 
promoted by varied agencies of civil society, but those that wanted to found ways to ask questions and express reservations, focusing on opportunities for learning. This might be in the staffroom, away from pupil hearing, implying assumptions about age-appropriate content, or in secondary schools through lesson content which encouraged pupils to question militaristic readings or armistice commemoration generally. For pupils, questioning is seen in scuffles over poppy wearing, singing the wrong words to hymns, or choice of Bible reading. Critique was framed, mostly, in ways that were unobtrusive, but mattered for those involved.

The emotional tenor of many accounts conveys anxiety, sadness, uneasiness, anger, and frustration; potentially responses to feelings of powerless in the face of an almost compulsory civic event and overwhelmed by the possibility of another war. These ceremonies touched a nerve, whether in a welcome or unwelcome way. Life at school and wider political and ideological engagements collided, and this could prove uncomfortable and unsettling. Yet notwithstanding a sense of being swept along by wider currents, norms and expectations, teachers and pupils strove in different ways to make sense of the event. Writing for Mass Observation might potentially have offered panellists a chance to reveal their 'true' thoughts and emotions while performing in public during a formal and ritualistic collective act. This sort of binary, however, should not be taken at face value. Even for pupils and teachers who offered a critique, might participating in a common commemorative act have been deemed a civic duty, perhaps unwelcome in some respects, but of value nonetheless for the school community, and potentially wider local and national communities, of which they were part?

1937 appears, with the benefit of hindsight, to have been a year with peculiar and distinctive features. In 1938 Mass Observation again gathered evidence about Armistice 
commemoration, this time through a survey rather than panellist accounts, and reported "an increase in emotional feeling about the two minutes' Silence". This "increase in emotional feeling" was interpreted in part as a response to the Munich crisis that Autumn which had reversed the trend of declining interest and focused attention less on the last War and more on the future, and in part as a result of gathering survey data from a different sort of respondent - on average, older, more working-class, and a more varied political mix than the national panel. 43 Such a perception of change highlights potential limitations of a close focus on accounts from a small number of individuals in one year. Nonetheless, the analysis in this article is offered as one way of gaining insights into the varied ways in which contemporaries sought to educate, and induct young people into thinking about, war and peace as a component of a broader agenda of education for citizenship, and the varied ways in which young people engaged with this agenda. It offers ways of investigating and conceiving of commemoration, children's agency, and militarism - and beyond this school's role in the production of democratic citizens - which speak to wider research agendas. Larger questions are raised. The complex intertwinings of the personal and individual and the public or communal are a powerful and consistent theme in research into commemoration and memorialization of conflict internationally. 44 How might parallel agendas play out in different geographical or institutional contexts of commemoration? How might narratives, tropes and symbols of commemoration vary? How do contemporaries, at different times and in different places, conceive the role of schools, and teachers and pupils within them, in commemorations of death in military conflict? Does this study highlight the potential to find other everyday "war stories", pedagogies of militarism through commonplace and inconspicuous objects and narratives which, deliberately or otherwise, encode the notion that war is inevitable and render alternative possibilities 
difficult to imagine? Or the potential to find other opportunities for promoting an internationalist or even pacifist cause, again with assumptions of a captive audience? 45 The up-closeness of Mass Observation accounts allows us to discern varieties of individual agentic expression in the face of unifying, top-down rituals and narratives. And these individual narratives tap into questions transcending particular times and geographical contexts about how children might learn about, and interpret and interrogate, major questions of global geopolitics and the societal impact of war and peace.

1 Day Survey Respondent (DSR) 421, November 11, 1937, Day Surveys, Mass Observation Archive (MOA), Sussex. All Day Survey Responses are November 11, 1937 unless stated otherwise. All MOA items were accessed via Mass Observation Online: http://www.massobservation.amdigital.co.uk.oxfordbrookes.idm.oclc.org.. 2 Jay Winter and Emmanuel Sivan, "Setting the Framework," in War and Remembrance in the Twentieth Century, ed. Jay Winter and Emmanuel Sivan (Cambridge: Cambridge University Press, 1999), 6-39, at 6. I perceive collective remembrance a more useful concept for these collective, performative rituals than the oft-used alternative of collective memory, particularly when the focus here is on many who have no direct memories of the First World War. Exemplifying many collective international projects and events see Timothy G. 
Ashplant, Graham Dawson and Michael Roper, ed., The Politics of War Memory and Commemoration (London: Routledge, 2000); Derek Mallett, ed., Monumental Conflicts? Twentieth-Century Wars and the Evolution of Popular Memory (London: Routledge, 2017); Mellon-Sawyer Post-War: Commemoration, Reconstruction, Reconciliation seminar series and conference, Oxford, UK, September 2017-July 2018.

3 Eric Hobsbawm, "Introduction," in The Invention of Tradition, ed. Eric Hobsbawm and Terence Ranger (Cambridge: Cambridge University Press, 1983), 1-14; Alex King, Memorials of the Great War in Britain (London: Bloomsbury, 1998), 195-97; Nicholas B. Dirks, "Ritual and Resistance: Subversion as a Social Fact," in Culture/Power/History. A Reader in Contemporary Social Theory, ed. Nicholas B. Dirks, Geoff Eley and Sherry B. Ortner (Princeton, New Jersey: Princeton University Press, 1994), 483-503; Betty Eggermont, "The Choreography of Schooling as Site of Struggle: Belgian Primary Schools, 1880-1940," History of Education 30 no. 2 (2001): 129-40.

4 Lucy Noakes, “A Broken Silence? Mass Observation, Armistice Day and 'Everyday Life' in Britain 1937-1941, Journal of European Studies 45 no. 4 (2015): 331-46, at 322; King, Memorials of the Great War in Britain, 16. See also Adrian Gregory, The Silence of Memory: Armistice Day, 1919-1946 (London: Bloomsbury, 1994), 24-33, 61-74; Dan Todman, The Great War, Myth and Memory (London: Bloomsbury Academic, 2013 (orig. 2005)), 49-58; Jay Winter, Remembering War: The Great War Between Memory and History in the Twentieth Century (New Haven: Yale University Press, 2006), chap. 6; Susannah Wright, “Internationalist Messages of War: The League of Nations Union in the Interwar Years," Constructing Messages of War Symposium (University of Oxford/Oxford Brookes University), Oxford, UK, May 17, 2018. 
5 Schools are referenced briefly in Mark Connelly, The Great War, Memory and Ritual (Woodbridge: Boydell Press, 2015 (orig. 2002)), 81-91; Gregory, Silence of Memory, 171; Noakes, “A Broken Silence?," 335-8.

6 Mass Observation gathered data on Armistice Day again in 1938 and 1941, but in different formats and using different methods (surveys and 'expert' observation). 1937 is the only year for which the data allows a close focus on the individual narratives of teachers and pupils in schools. Quotation is from: Charles Madge and Tom Harrisson (eds), First Year's Work 1937-38 (London: Lindsay Drummond, 1938), 108.

7 For example, "Force against Aggression," The Times, October 8, 1937, 9; "Gas-Masks in Reserve," The Manchester Guardian, January 13, 1937, 10; “Air-Raid Precautions and their Cost," The Manchester Guardian, March 5, 1937, 10. See also Lucy Noakes, "'Serve to Save': Gender, Citizenship and Civil Defence in Britain 1937-41, Journal of Contemporary History 47 no. 4 (2012): 734-53.

8 The Manchester Guardian, November 12, 1937, 11; The Times, November 12, 1937, 10; Hansard House of Commons Debate, November 11, 1937, vol. 328 c.1843.

9 For example DSR 102, 421.

10 B. J. Elliott, "The League of Nations Union and History Teaching in England: A Study in Benevolent Bias," History of Education 6 no. 2 (1977): 131-41; Helen McCarthy, The British People and the League of Nations (Manchester: Manchester University Press, 2011), chap. 4; James Mangan, Manufactured Masculinities (Abingdon: Routledge, 2012), chap. 12; William E. Marsden, “'Poisoned History': A Comparative Study of Nationalism, Propaganda and the Treatment of War and Peace in the Late Nineteenth- and Early Twentieth-Century School Curriculum," History of Education 29 no. 1 (2000): 29-47; C. B. Otley, "Militarism and 
Militarization in the Public Schools, 1900-1972," British Journal of Sociology 29 no. 3 (1978): 321-39; Christopher Watkins, "Inventing International Citizenship: Badminton School and the Progressive Tradition between the Wars," History of Education 36 no. 3 (2007): 315-38; Susannah Wright, "Creating Liberal-Internationalist World Citizens: League of Nations Union Junior Branches in English Secondary Schools, 1919-1939," Paedagogica Historica, published online: https://doi.org/10.1080/00309230.2018.1538252.

11 Angela Bartie et al., “And Those Who Live, How Shall I Tell their Fame?' Historical Pageants, Collective Remembrance and the First World War, 1919-39," Historical Research 90 no. 249 (2017): 636-31; Rob Freathy, "The Triumph of Religious Education for Citizenship in English Schools, 1935-1949," History of Education 37 no. 2 (2008): 295-316; Tom Hulme, "Putting the City Back into Citizenship: Civics Education and Local Government in Britain, 1918-45," Twentieth Century British History 26 no. 1 (2015): 26-51; Susannah Wright, Morality and Citizenship in English Schools. Secular Approaches, 1897-1944 (Basingstoke: Palgrave Macmillan, 2017).

12 Gregory, Silence of Memory; Connelly, Great War, Memory and Ritual, 139-229; Wright, "Internationalist Messages of War".

13 For local authority guidelines see Teachers' World, November 18, 1931, 277; The Manchester Guardian, November 9, 1937, 13; The Schoolmaster, November 7, 1935, 674 and November 11, 1937, 826. Resources featured most years in, for example, Teachers' World, The Schoolmaster, Times Educational Supplement.

14 Times Educational Supplement, November 17, 1934, Home and Classroom Section, i; E. J. Orford, "I was a Militarist," The Schoolmaster, November 7, 1935, 670, 690; X-Ray, "Letter to the Editor," The Schoolmaster, October 28, 1937, 764. 
15 DSR 572, 308; Karen Sánchez-Eppler, "In the Archives of Childhood," in The Children's Table, ed. Anna Mae Duane (Athens: University of Georgia Press, 2013), 213-38, at 225-6. 16 See Mona Gleason, “Avoiding the Agency Trap: Caveats for Historians pf Children, Youth, and Education," History of Education 45 no. 4 (2016): 446-59; Susan Miller, "Assent as Agency in the Early Years of the Children of the American Revolution," Journal of the History of Childhood and Youth 9 no. 1 (2016): 48-65.

17 Sánchez-Eppler, "In the Archives of Childhood," 215-16; Gleason, "Avoiding the Agency Trap".

18 Tom Harrisson, Humphrey Jennings, Charles Madge, "Letter to the Editor," The New Statesman and Nation, January 30, 1937, 115; Charles Madge and Tom Harrisson, MassObservation (London: Frederick Muller Ltd, 1937), 10. For details on Mass Observation see James Hinton, The Mass Observers: A History, 1937-1949 (Oxford: Oxford University Press, 2013).

19 Madge and Harrisson, Mass-Observation, 32; Hinton, Mass Observers, chap. 3. 20 Mass Observation, "Directive to New Observers," Directives [File Report-A4], MOA; DSR 522.

21 "Mass Observation Bulletin for October 1937," 3, Directives [File Report-A4]; Hinton, Mass Observers, 62. Information about panellists' schools is found scattered across different monthly submissions.

22 Responses to questions in the September Bulletin about why they joined Mass Observation, inter alia. On Mass Observation and left-wing politics and 'authenticity' see, respectively, Alexandre Campsie, "Mass-Observation, Left Intellectuals and the Politics of Everyday Life," English Historical Review 131 no. 548 (2016): 92-121; Hester Barron and 
Claire Langhamer, "Feeling through Practice: Subjectivity and Emotion in Children's

Writing," Journal of Social History 51 no. 1 (2017): 101-23.

23 DSR 553, 308, 225.

24 DSR 253. On internationalism in armistice commemoration see LNU, Headway,

December 1924, 238 and December 1925, 239; Gregory, Silence of Memory, 124-5, 150-52.

25 DSR 522, 35. On wider debates see Connelly, Great War, Memory and Ritual, 191-96.

26 DSR 102, 188, 385, 572.

27 DSR 35, 112, 385, 421, 538, 404. On poppies see Gregory, Silence of Memory, chap. 3;

Jennifer Iles, "In Remembrance: The Flanders Poppy," Mortality 13 no. 3 (2008): 201-21.

28 DSR 434, 225, 404, 424, 552; Otley, “Militarism and Militarization in the Public Schools," 330-32.

29 DSR 8, 424, 522.

30 DSR 342, 8, 522, 484.

31 DSR 385.

32 DSR 421, 572, 308.

33 Gregory, Silence of Memory, 12, 18; DSR 136, 434, 484.

34 DSR 461 (emphasis in original), 421, 295; Connelly, Great War, Memory and Ritual, 83-

91.

35 Otley, "Militarism and Militarization in the Public Schools," 332; DSR 484.

36 DSR 385, November 12, 1937.

37 DSR 308, 385.

38 DSR 102, 188. 
39 DSR 484, 552, 65. On contemporary responses to white poppies see "Armistice Day in the North," The Manchester Guardian, November 12, 1937, 12; Gregory, Silence of Memory, $152-9$.

40 DSR 434, November 12, 1937; DSR 8, 421, 484, 520, 522.

41 DSR 484, 522.

42 King, Memorials of the Great War in Britain, 16.

43 Mass Observation, “M.O” [Bulletin for December 1937], 2, Directives [File Report A8], MOA; Noakes, “A Broken Silence?," 338-40.

44 For example, Ashplant, Dawson and Roper, The Politics of War Memory and Commemoration); Mallett, ed., Monumental Conflicts? Mellon-Sawyer Post-War:

Commemoration, Reconstruction, Reconciliation seminar series.

45 See J. Marshall Beier, "War Stories: Militarized Pedagogies of Children's Everyday," in The Militarization of Childhood, ed. J. Marshall Beier (New York: Palgrave, 2011), 95-110; Sarah Glassford, "Practical Patriotism: How the Canadian Junior Red Cross and its Child Members Met the Challenge of the Second World War," Journal of the History of Childhood and Youth 7 no. 2 (2014): 219-42. 